\title{
セラミックスのレーザ割断におけるき裂発生位置の解析的検討*
}

\author{
鶴 来 昌 樹*1, 町·田 隆 志*1 \\ 井本 克 之ं2, 澤 田篤*3

\section{Analytical Study on Crack Initiation Position in Laser Beam Cleaving of Ceramics}

\author{
Masaki TSURUKI*4, Takashi MACHIDA, \\ Katsuyuki IMOTO and Atsushi SAWADA \\ *4 Mechanical Engineering Research Laboratory, Hitachi Ltd., \\ 502 Kandatsu, Tsuchiura-shi, Ibaraki, 300-0013 Japan
}

\begin{abstract}
Laser cleaving is expected to become a new method for cutting inorganic brittle materials such as ceramics and glasses without generating particles or microcracks. However, an initial crack caused by this method often occurs at a short distance from a cutting line. By using computer simulation, we investigated the dependence of crack-initiation behavior on cutting conditions such as beam radius, beam movement velocity, and beam-injection position. The simulation shows that we can reduce the distance between the cutting line and an initial crack by selecting appropriate cutting conditions. When the beam-injecting position is fixed, positioning the injection near the plate edge effectively reduces the distance between the cutting line and the initial crack, while beam radius does not significantly affect the distance. On the other hand, when the beam-injection position is moved during cutting, reducing beam radius and starting the injection at the plate edge or outside of the plate are effective in reducing the distance.
\end{abstract}

Key Words: Finite Element Method, Ceramics, Thermal Stress, Brittle Fracture, Almina, Laser Beam Cleaving, Crack Initiation, Point Heat Source

\section{1. 緒言}

セラミックスやガラスなどの無機脆性材料の切断 加工技術としては，ダイヤモンド砥石による砥粒加工 やダイヤモンドスクライバなどによりき裂を発生させ たのちに，曲げ荷重を負荷して割断するスクライブ加 工，レーザにより部材を溶融させるレーザ浴融加工， ワイヤ放電加工などが一般的である。しかしここれら の加工方法は，(1)マイクロクラックなどの加工損傷 の発生, (2)切り居の発生、(3)研削液の使用, (4)加 工面近傍の熱的変質などの欠点がある。清浄な環境が 要求される、半導体ウェハなどの加工においては歩留 り向上のために、上記課題の克服が求められている(1).

レーザ割断は，レーザをビーム状に小さく絞って 照射し，部材に急激な温度分布を形成することにより 局所的に発生する大きな熱応力を利用して，き裂進展 により部材を切断する加工方法であり(1)(2)(3)(4)，上記課

*原稿受付 2001 年 5 月 14 日.

*1 正員，(株) 日立製作所機械研究所(画300-0013 土浦市神立 町 502).

*2 日立電線(株)オプトロニクス研究所( 高町 5-1-1).

*3 日立電線 (株)土浦工場 (亚 300-0026 土浦市木田余町 3550).

E-mail : turu@merl.hitachi.co.jp
題を克服できる無機材料加工技術として，半導体やデ イスプレイなどの分野で期待されている. しかし，熱 応力によるき裂進展を利用するため，初期き裂の発 生方向がレーザの進行方向に対して偏向する課題があ る.

図1にレーザ割断における初期き裂の偏向の例を 示す。本例は，アルミナ基板 $50 \mathrm{~mm} \times 50 \mathrm{~mm} \times 1.5 \mathrm{~mm}$ の 1 辺の中央端から $8 \mathrm{~mm}$ の位置にレーザを静止照射 したときのき裂の発生状況の 1 例である. 写真は，き 裂を可視化するためにインクで染色している．き裂は 基板端から発生し, レーザ照射位置に向って進展して いる. き裂のほぼ先端がレーザの照射位置である. 期 待したき裂発生位置は、レーザ照射位置から基板端に 垂線を下ろした交点（図中点A）であるが，実際に発 生した位置は若千右に偏向している。レーサ照射位置 から基板端への垂線と、レーザ照射位置とき裂発生位 置を結ぶ線分とのなす角度を偏向角と定義すると, 本 例では偏向角は約 $5^{\circ}$ である. き裂近傍に広がる㓌は インクのにじみである. 
初期き裂の発生方向の偏向を防止するためには， 部材に予き裂を与える方法が一般的であり，従来から， 点熱源により部材に生じる温度分布やき裂の進展挙動

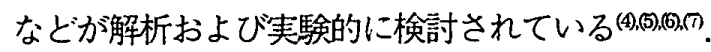

しかし，予き裂を与えることは加工工程の增加と なり望ましいことではない。そこで著者らは予き裂を 与えずに，初期き裂の発生方向の偏向を低减すること を目的に，(a)レーザ照射位置，(b)レーザビーム径， (c)レーザ移動速度などの加工条件がき裂発生位置に 及ぼす影暨について熱応力解析により検討した。

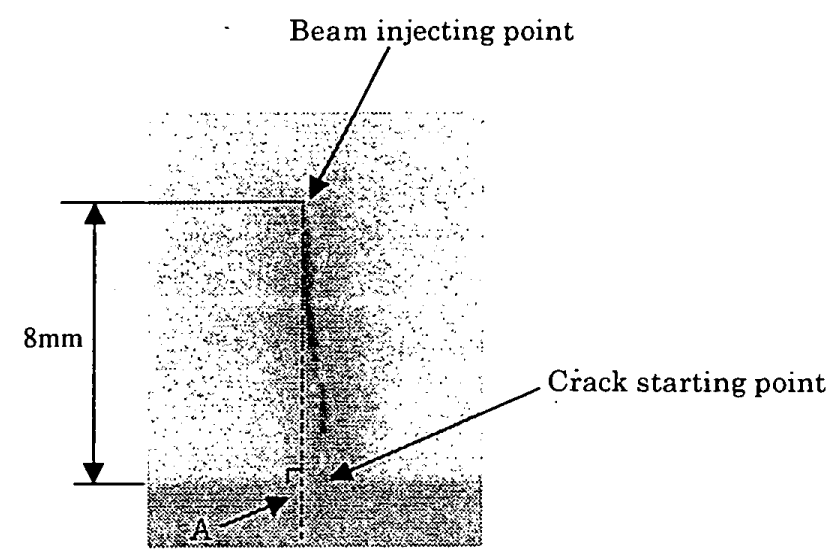

Fig. 1 An example of initial crack by laser beam cleaving

\section{2. 解析モデル}

本研究に用いたレーザ割断の模式図を図 2 に示す。 本モデルでは, 出力 $P[\mathrm{~W}]$ の $\mathrm{O}_{2}$ レーザをアルミナ 基板に照射する。レーザは基板からオフセット距離 $L$ $[\mathrm{mm}]$ の位置に焦点を結び基板上では半径 $r[\mathrm{~mm}]$ の円 形状領域に照射される．また，レーザは基板端中央か ら対向する基板端に向かって，基板を 2 等分するよう に速度 $v[\mathrm{~mm} / \mathrm{s}]$ で移動することとする．これを有限 要素法を用いた熱弾性解析により模擬した。図 3 に解 析モデルを示す．アルミナ基板の形状は，50 $\mathrm{mm} \times$ $50 \mathrm{~mm} \times 1.5 \mathrm{~mm}$ とし，解析は割断面を対称面とする $1 / 2$ 対称モデルで行った。レーザによる入熱は， 2 次 元正規分布の内部発熱を仮定した. アルミナ基板のレ 一サ照射側表面には板厚方向に要素 1 分割分のみを,

厚さ $0.01 \mathrm{~mm}$ の内部発熱要素として作成した. 各要 素の発熱量は, 要素の重心位置の発熱量を与えた。熱 的境界条件は，基板表面からの熱輸送として平板の自 然対流冷却の熱伝達を仮定した。基板端からビーム 照射領域の中心までの距離を照射位置 $d[\mathrm{~mm}]$ とした.

要素分割寸法は，レーザ照射を模擬する内部発熱 要素はレーザ移動方向及びその垂直方向には $025 \mathrm{~mm}$, 板厚さ方向には $0.01 \mathrm{~mm}$ とした. それ以外領域ではレ

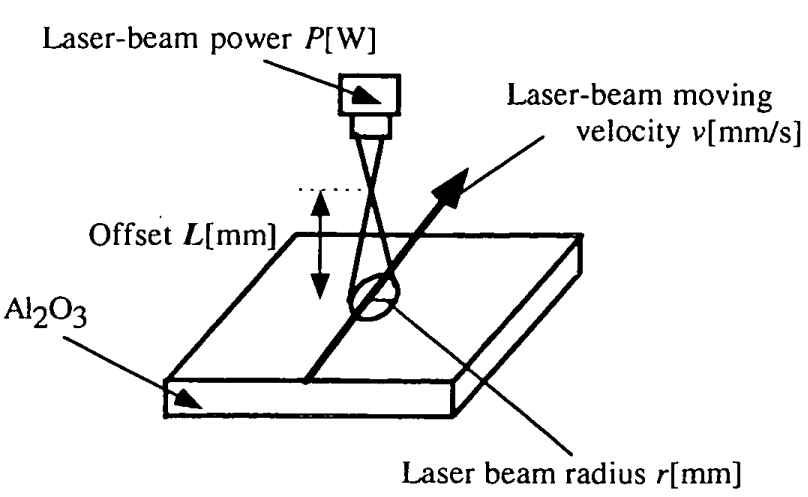

Fig. 2 Overview of laser beam cleaving

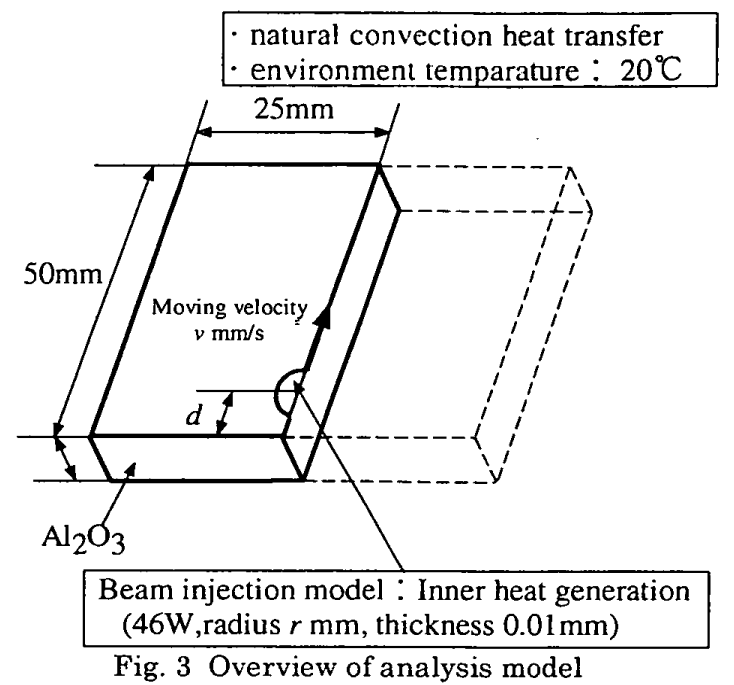

Table 1 Material properties used in numerical analysis

\begin{tabular}{|l|c|}
\hline Young's modulus [GPa] & 343 \\
\hline Poisson's raio & 0.25 \\
\hline $\begin{array}{l}\text { Coefficient of linear thermal } \\
\text { expansion [1/K] }\end{array}$ & $7.1 \times 10^{6}$ \\
\hline Thermal conductivity [W/m·K] & 25.1 \\
\hline $\begin{array}{l}\text { Specific heat capacity at constant } \\
\text { volume }\left[\mathrm{J} / \mathrm{m}^{3} \cdot \mathrm{K}\right]\end{array}$ & 3017 \\
\hline
\end{tabular}

一ザ照射領域から離れるに従い，要素寸法を大きくし， 最大要素の寸法は約 $4.5 \mathrm{~mm} \times 4.5 \mathrm{~mm} \times 0.4 \mathrm{~mm}$ となる ようにした.

解析に用いた物性値を表 1 に示す. 物性值の温度依 存性はないと仮定した.

\section{3. 静止熱源解析}

3.1 静止智射時の応力分布 まず, レーザを静 止して照射した場合の基板内の発生応力について検討

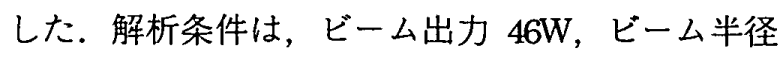
$125 \mathrm{~mm}$ ，照射位置は，ビームの照射領域の中心を基 板端から $5.0 \mathrm{~mm}$ とした。

ビーム出力は基板の強度を考慮して，以下の考え 方で選定した，一般にアルミナの大気中の強度はおよ 
そ200MPa〜 450MPaである(ほ)(10). 予め予備解析を行 い, ビーム出力を $46 \mathrm{~W}$ とした場合, その他の解析条 件を変動させた時に，多くの条件でアルミナ基板端に $200 \mathrm{MPa} \sim 450 \mathrm{MPa}$ 以上の応力が発生することを確認 した. また，実験的にもこの条件でき裂が発生するこ とを確認した。

まず非定常解析の結果を示す，図 4 に，基板端中 央上面に発生する温度と最大主応力の時間変化を示す。 基板端中央上面にき裂を生じさせることを目的として いるため，その位置の温度と応力に着目した．解析時 間間隔は 0.01 秒とし， 1 秒後まで解析した。

温度は， 0.01 秒後には室温から $250^{\circ} \mathrm{C}$ に上昇し， 0.05 秒後には $380^{\circ} \mathrm{Cを}$ 示し, 定常時の約 $95 \%$ となる.

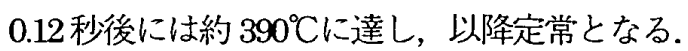

最大主応力は，0.01 秒後には約 $400 \mathrm{MPa}$ に達し， 定常状態の $90 \%$ となる。.0.04 秒後には $450 \mathrm{MPa}$ とな り以降定常状態を示す。

温度, 応力とも短時間で定常状態に達し, この状 態で最大值を示すことから, 以下では定常解の結果を もとに議論することとした。

図 5 に定常状態での温度分布, 図 6 に最大主応力 分布を示す. 解析は $1 / 2$ 対称を仮定しているため, 割 断面を対称面とする 12 の部分図に表示した. ビーム 照射領域中心での温度は $1000^{\circ} \mathrm{C}$ 超え, ビーム照射 領域の外側では急激に温度か泜下する．ビーム照射領 域から最も遠い基板角部ではほぼ室温の状態である。

また，ビーム照射領域に近い基板端中央では約 $390^{\circ} \mathrm{C}$ を示した。

主応力の分布は, ビーム照射領域内は隣接する領 域と比較して高温となるため, 周囲の拘束により $3 つ$ の主応力とも圧縮を示し，圧縮応力場となるが，ビー 么照射領域加離れると，温度の急激な低下に従い,

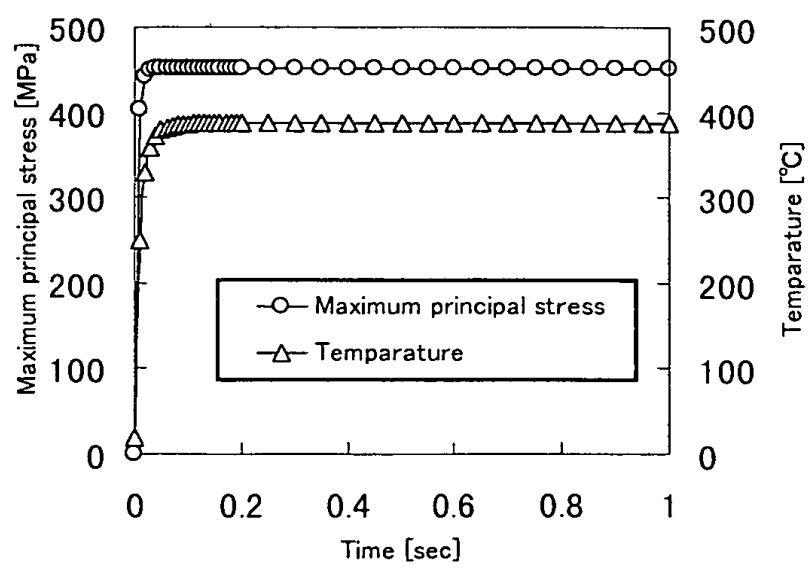

Fig. 4 Change of maximum principal stress at the center of plate
3つの主応力とも引張となり, 引張応力場に転じる. 最大引張応力はビーム照射領域に近い側の基板端中央 に発生し，約 $450 \mathrm{MPa}$ を示す。

初期き裂の発生方向の偏向とは，ビーム照射で想 定する割断開始位置の基板端中央と初期き裂の発生位 置が一致しないことであるから，基板端での応力分布 に着目する. また，基板端での最大主応力の方向が基 板端に平行であるので，基板端での初期き裂の発生に ついては最大主応力で評価できる。

図 7 に; 基板端中央（1/2 対称面）加基板端に沿 った最大主応力分布を示寸．最大主応力は基板端中央

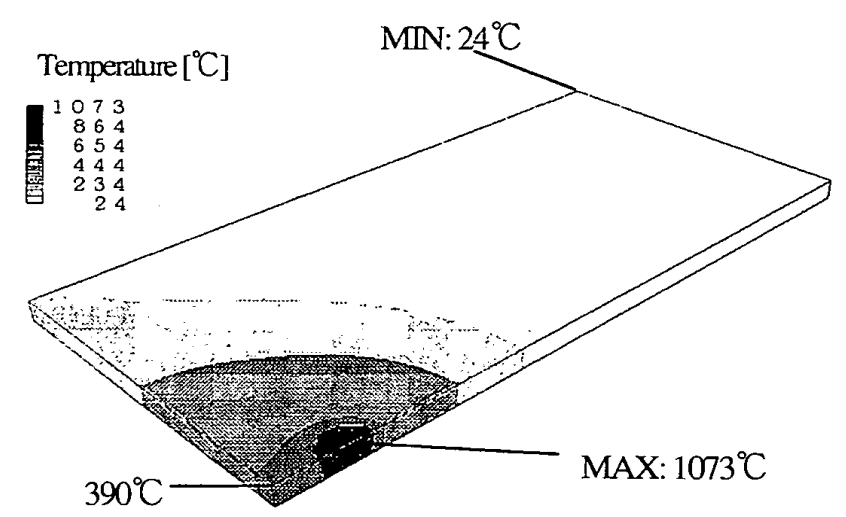

Fig. 5 Distribution of temperature

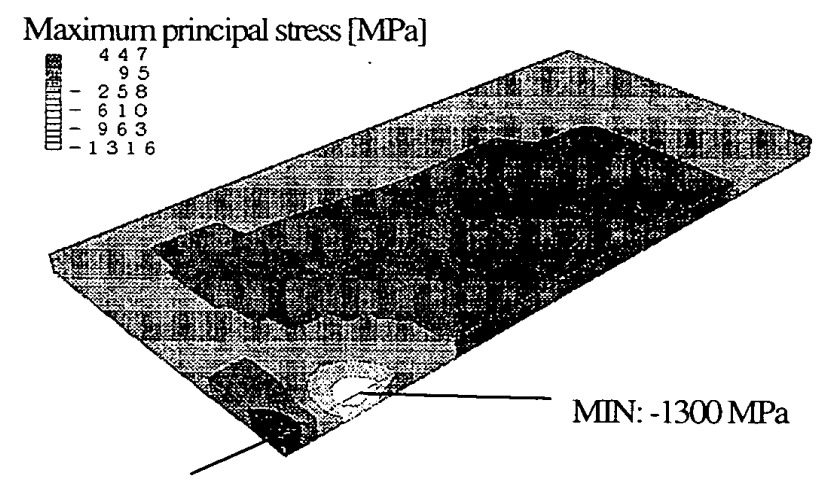

MAX: $450 \mathrm{MPa}$

Fig. 6 Distribution of maximum principal stress

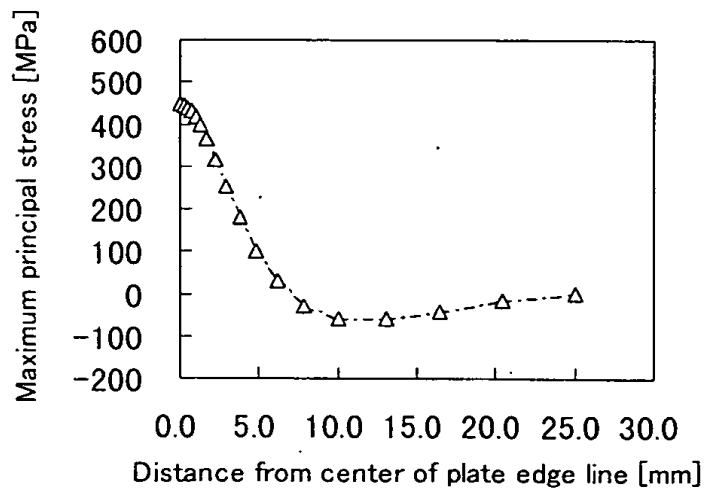

Fig. 7 Distribution of maximum principal stress at the plate edge 
で弓張の最大值を示し，中央から離れるに従い低下し， 压縮応力となる。

初期き裂は基板端中央に生じる最大主応力が高い ほど基板端中央に生じ易くなる。 また，き裂は引張応 力場で生じると考えられるので，基板端中央近傍の引 張応力場となる領域が小さいほど初期き裂の発生する 位置は基板端中央に近ついていく．以上から，基板端 中央の応力は高く，その周囲では，基板端に沿って急 诶に応力が低下する最大主応力分布を形成することが 初期き裂の偏向を抑止するのに有効であると考えられ る.

本章では, 静止照射の場合のビーム照射位置とビ 一ム径が初期き裂の発生方向の偏向に及ぽす影響につ いて検討した.

3.2 レーザ照射位置の影翠 ビーム照射位置を基 板端からそれぞれ $1.75 \mathrm{~mm} ， 3.75 \mathrm{~mm} ， 5.0 \mathrm{~mm}$ 内部之 した解析を行った。レーザの出力は $46 \mathrm{~W}$ ，ビーム径 は $1.25 \mathrm{~mm}$ である. 図 8 に基板端中央から基板端に沿 った最大主応力分布を示す．横軸は基板端中央（1/2 対称面）から基板端に沿った距離を示し，縦軸は発生 する最大主応力を示す，照射位置が基板端に近いほど 発生応力が高くなるとともに，急峻な分布となる。し たがって，初期き裂発生時の偏向を抑止するためには 照射位置を基板端に近づける方が良いことがわかる。

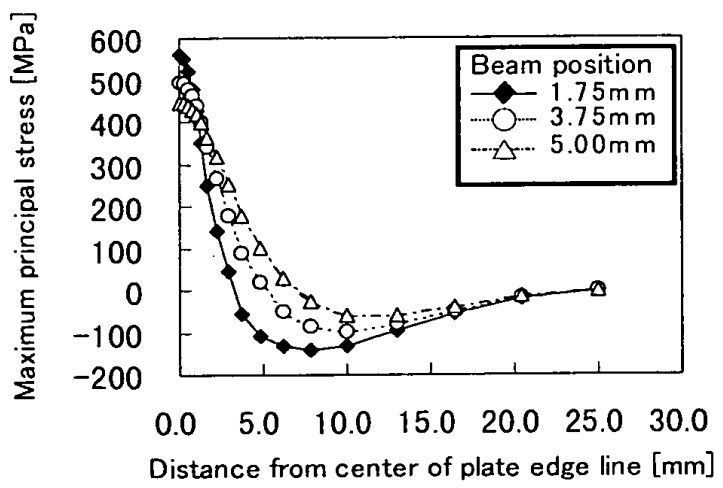

Fig. 8 Distribution of maximum principal stress for different beam positions

3.3 レーザビーム径の影響 ビームの出力を $46 \mathrm{~W}$ に固定し，ビーム径を $1.25 \mathrm{~mm}$ に加えて， $1.00 \mathrm{~mm}$, $0.75 \mathrm{~mm}$ とした場合について解析を行った。照射位置 は基板端から $3.75 \mathrm{~mm}$ の位置とした. 図 9 に,ビー 厶半径を $0.75 \mathrm{~mm}, 1.00 \mathrm{~mm}$ としたときの温度分布を 示し, 図 10 に,ビーム半径が $0.75 \mathrm{~mm}, 1.00 \mathrm{~mm}$, $1.25 \mathrm{~mm}$ それぞれの場合の基板端中央（1/2 対称面） から基板端に沿った最大主応力の分布を示す。

図 5 および図 9 より，ビーム半径を小さくすると ビーム照射領域中心の最高温度は高くなり、ビーム半
径が $0.75 \mathrm{~mm}$ の場合は最高温度が $1600^{\circ} \mathrm{C}$ 超える. これは同じ出力のビームがより狭い領域に入射するこ とによる.

しかしながら，図 10 の基板端に沿った最大主応力 の分布は，各ビーム半径ともほとんど重なっており， 基板端に発生する引張応力の大きさ, 分布は, ビーム 半径が $1.25 \mathrm{~mm}$ から $0.75 \mathrm{~mm}$ と小さくなってもあま り変わりないことがわかる.これは, 基板端に発生す

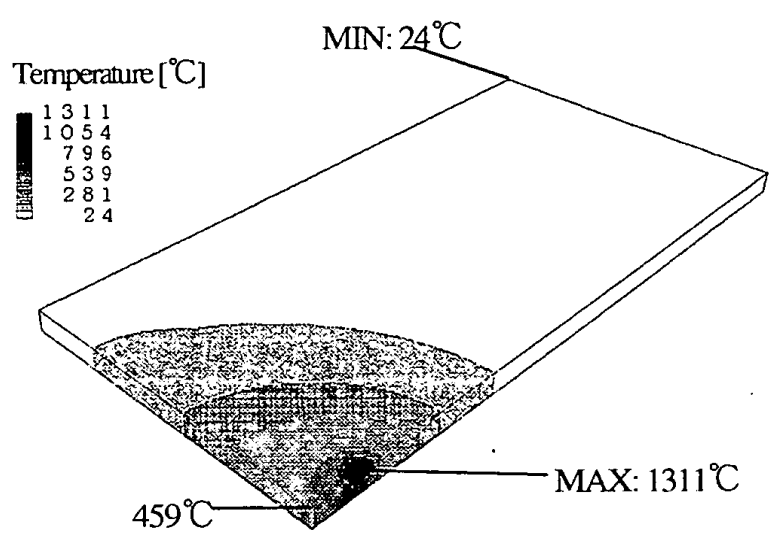

(a) beam radius $=1.00 \mathrm{~mm}$

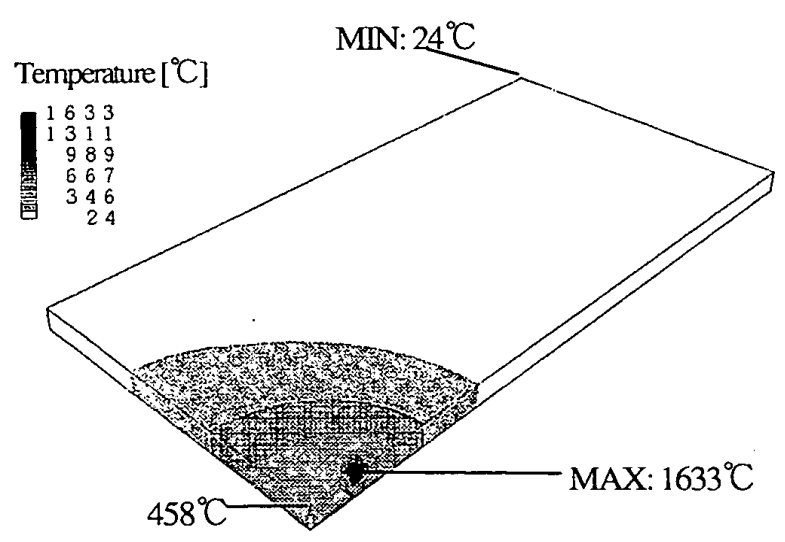

(b) beam radius $=0.75 \mathrm{~mm}$

Fig. 9 Distribution of temperature for different beam radii

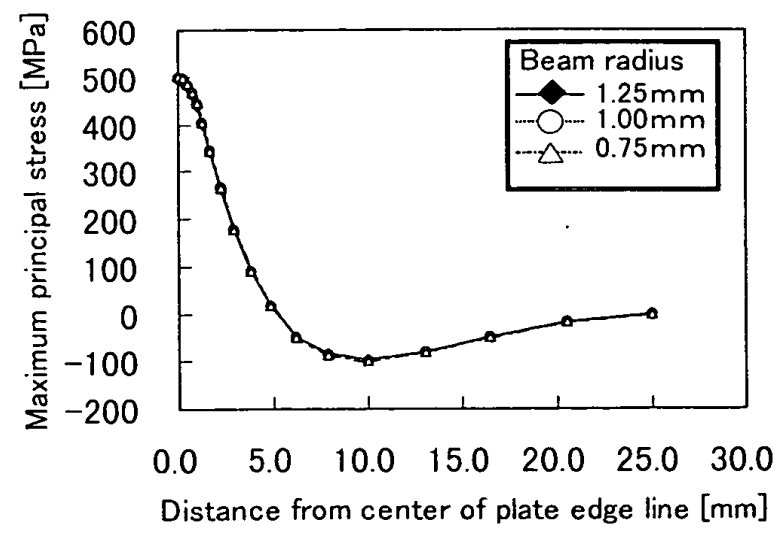

Fig.10 Distribution of maximum principal stress for different. heam radii 
る熱応力は，最高温度よりも基板全体の温度分布に起 因しており，本解析では，ビーム出力が等しいことと ビーム半径の変化量が基板寸法や基板端から照射位置 までの距離に比へ小さいために，基板全体としての温 度分布には大きな差が生じなかったためと考えられる。 したがって，ビーム径が大きく変化しないならば，ビ 一ム径の初期き裂の発生に及ほ影響は小さいと考え られる。

以上まとめると，レーザを静止して照射する場合， ビームの照射位置が基板端に近いほど初期き裂の偏向 を抑止する効果がある．また，ビーム径の影響は小さ いことがわかる.

\section{4. 移動熱源解析}

4.1 移動照射時の応力分布 次にビームの移動を 考慮した移動熱源による非定常解析を行った. ビーム を基板外から基板内一移動させて照射していく場合の 典型的な温度と応力分布の変化について検討した. ビ

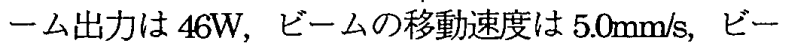
ム半径は $125 \mathrm{~mm}$ とした。レーザ照射開始より 1 秒後 までを，時間間隔を 0.05 秒，解析ステップ数を 20 ス テップで解析した。

図 11，12 に，代表的な時刻での温度分布と最大主 応力分布を示す．温度は基板端中央近傍がレーザの入 射とともに急激に上昇し， 0.25 秒後には $1016^{\circ} \mathrm{C}$ に達 する. その後, レーザの移動にともない最高温度の位 置は少しづつ前方に移動しながら温度上昇をつづけ, 0.4 秒後には $1300^{\circ} \mathrm{C}$ になる. 高温領域も徐々に広がり， ほぼレーザのビーム径に一致する. 0.5 秒後にはビー ムがすべて基板内に入射し，ビーム移動につれて照射 領域の最高温度は若干低下しながら移動していく. 最 低温度は基板隅で室温程度である。

移動に伴い発生する応为は, ビーム入射初期には 高温領域が基板端中央に集中しているため，基板端中 央か汪縮応力場となり, 基板端中央の下面側に最大引 張応力が発生する. ビームの移動に伴い, 圧縮応力場 は前方に移動し, 引張応力場もそれにともない下面か ら上面に拡大して，0.4 秒後には最大の引張応力の発 生位置が基板端中央上面になり、0.5 秒後には最大応 力は約 700MPaになる。

基板端中央上下面の応力の時間変化を図 13 に示す. 基板上面では，レーザ入射当初は基板端が高温領域と なるため，圧縮応力場となり，ビームの移動にともな い高温領域が移動するにつれ，急激に引張応力に変わ り，0.5秒後に最大応力になり以後緩やかに減少する. 基板下面はビーム入射当初より微小ながら弓張応力が
発生し，時間ととも緩やかに増加し，1.0 秒後には上 下面とも発生応力は等しくなる。

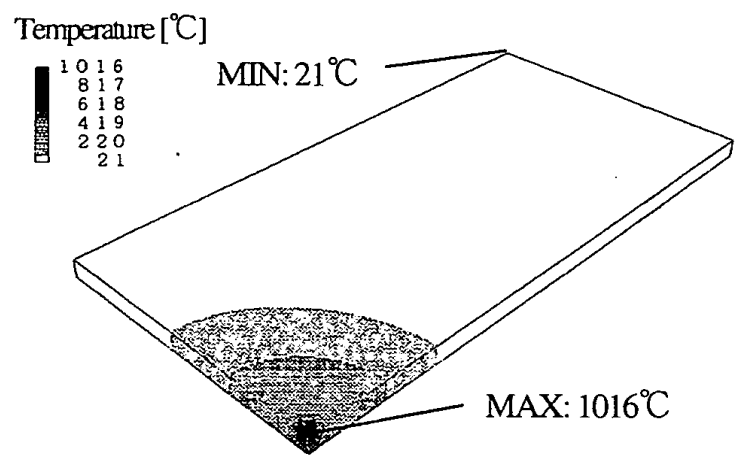

(a) time $=0.25 \mathrm{sec}$, step $=5$ setps

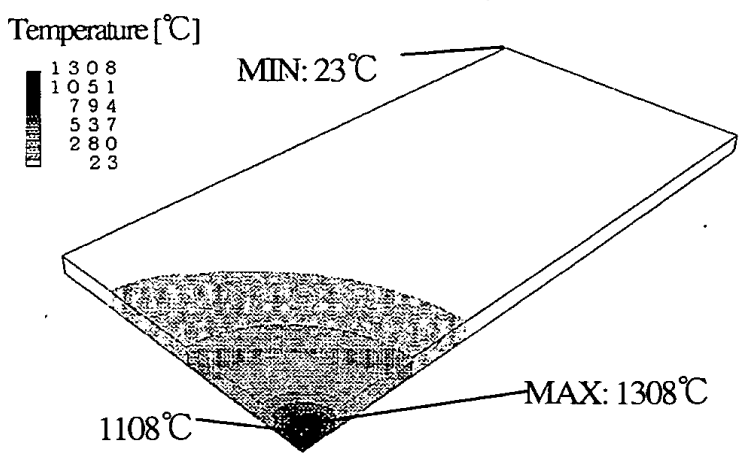

(b) time $=0.4 \mathrm{sec}$, step $=8$ setps Temperature $\left[{ }^{\circ} \mathrm{C}\right]$

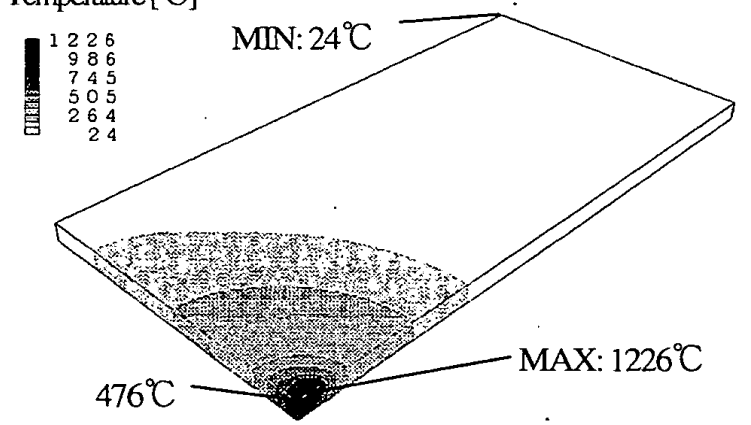

(c) time $=0.5 \mathrm{sec}$, step $=10$ setps

Temperature $\left[{ }^{\circ} \mathrm{C}\right]$

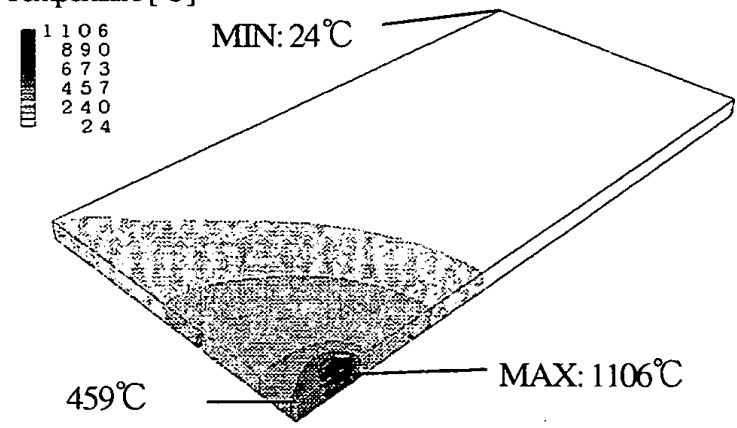

(d) time $=1.0 \mathrm{sec}$, step $=20$ setps

Fig. 11 Distribution of temperature for different beam radii 
図 14 には，基板端上面の基板端中央から基板端に 沿った最大主応力分布の時間変化を示す．ビーム入射 直後は基板端中央か照射による最高温度点であるため，

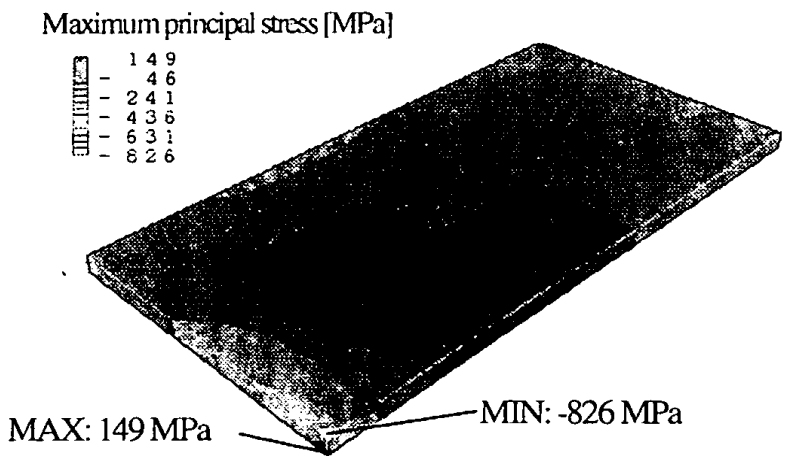

(a) time $=0.25 \mathrm{sec}, \quad$ step $=5$ setps Maximum principal stress $[\mathrm{MPa}]$

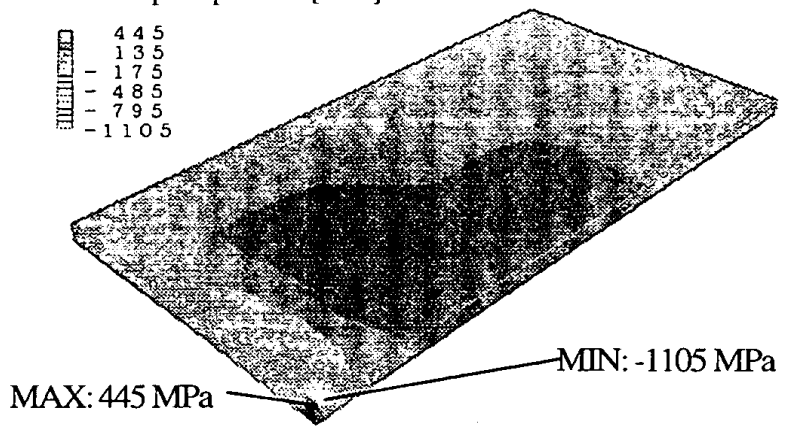

(b) time $=0.4 \mathrm{sec}$, step $=8$ setps Maximum principal stress [MPa]

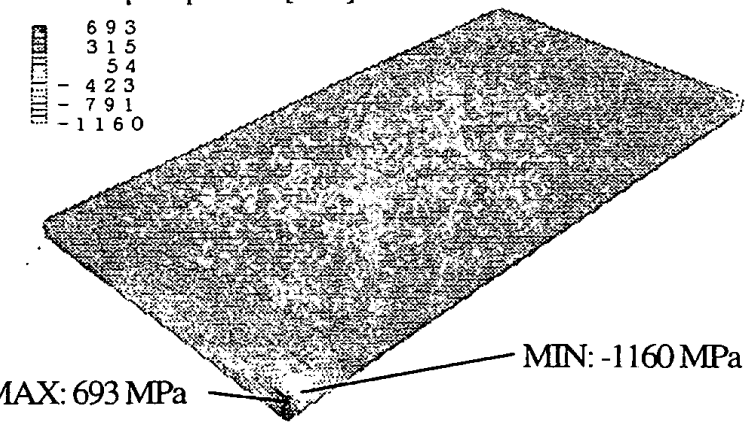

(c) time $=0.5 \mathrm{sec}$, step $=10$ setps

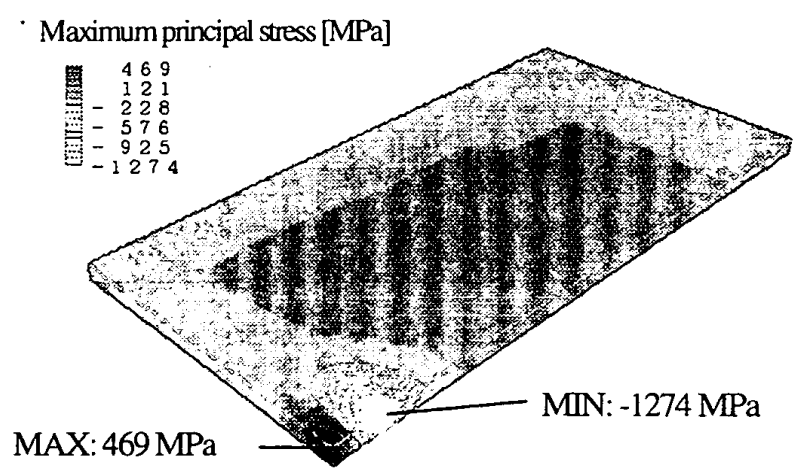

(d) time $=1.0 \mathrm{sec}$, step $=20$ setps

Fig. 12 Distribution of maximum principal stress for different beam radii

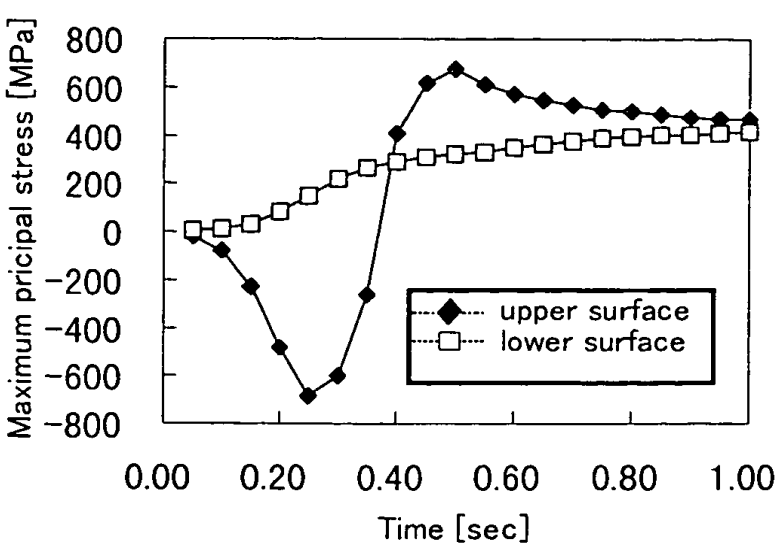

Fig. 13 Change of maximum principal stress at the center of plate edge

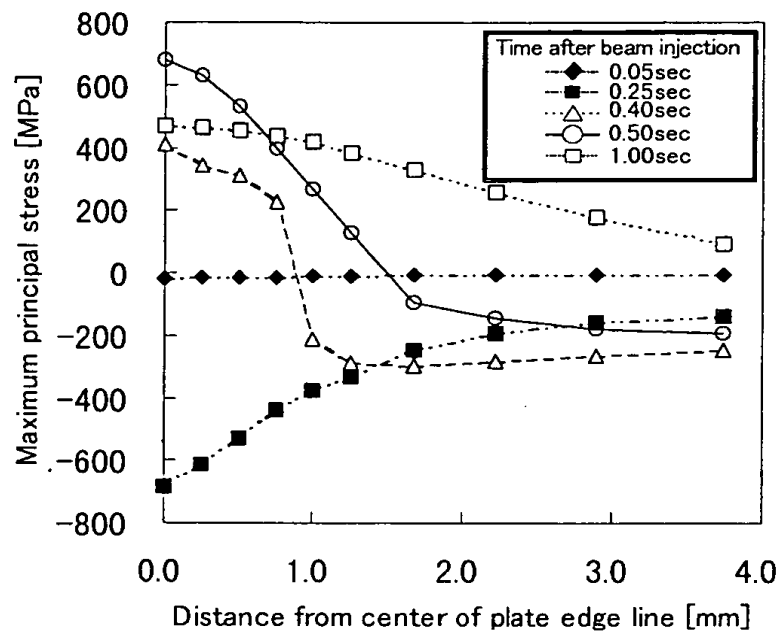

Fig. 14 Distribution of maximum principal stress for different beam iniection time

ビーム近傍を中心に圧縮応力場を示す. 約 0.4 秒後に は，ビームが移動して基板端中央近傍が最高温度領域 から外れるため, 当該部のみに引張応力か発生し，急 峻な応力分布を示す．基板端中央がビーム照射領域外 となる約 0.5 秒後に基板端中央に最大応力が発生し, その後極大值は小さくなりながら，引張応力場の領域 は拡大していくことがわかる.

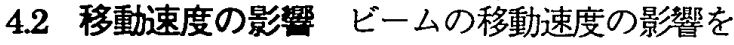
検討するため，移動速度が $5.0 \mathrm{~mm} / \mathrm{s} ， 10.0 \mathrm{~mm} / \mathrm{s}$, $15.0 \mathrm{~mm} / \mathrm{s}$ の場合の解析を行った. ビーム出力は $46 \mathrm{~W}$, ビーム半径は $1.25 \mathrm{~mm}$ とした。

図 15 に各移動速度で, 最大応力が発生した時刻の 基板端上面の基板端中央から基板端に沿った最大主応 力分布を示す.

最大応力の発生した時刻は各移動速度で異なる。 $5.0 \mathrm{~mm} / \mathrm{s}$ では，基板端から $1.25 \mathrm{~mm}$ 離れた位置にビ 一ムが移動した 0.5 秒後に基板端中央上面で最大主応 力か採 $700 \mathrm{MPa}$ になる. $10.0 \mathrm{~mm} / \mathrm{s}$ では基板端からの $125 \mathrm{~mm}$ 離れた位置にビームの中心が移動した 025 秒 
後に基板端中央上面で最大主応力が約 $640 \mathrm{MPa}$ にな る. $15.0 \mathrm{~mm} / \mathrm{s}$ では， $1.22 \mathrm{~mm}$ 離れた位置にビームが 移動した 0.1625 秒後に基板端中央上面で最大主応力 が約 $600 \mathrm{MPa}$ になる。、いずれの場合も最大応力が発 生している時刻は，前節で述べた，基板端中央がビー 么照射領域外となる，ビ一ムの中心位置が基板端から $1.25 \mathrm{~mm}$ の位置に移動したときにほぼ一致した。

図 15 より，最大氻が発生する特刻の基板端に沿 った主応力分布は，いずれの移動速度の場合もほほ同 一であるが，基板端中央に発生する最大応力の值は移 動速度が低いほど高くなる。

以上より，ビームの移動速度は低い方が，割断は 容易になるが，割断の速度は低くなる．また，引張応 力場の分布には差がないので, 初期き裂の発生方向の 偏向にはあまり影響がない。

4.3 ビーム径の影響 ビーム径の影響を検討する ために，ビーム径を $1.25 \mathrm{~mm}, 1.00 \mathrm{~mm}, 0.75 \mathrm{~mm}$ と した解析を行った. ビーム出力は $46 \mathrm{~W}$, ビーム移動 速度は $10 \mathrm{~mm} / \mathrm{s}$ とした.

図 16 に，それぞれのビーム径で最大応力か発生し た時刻の，基板端上面の基板端中央から基板端に沿っ

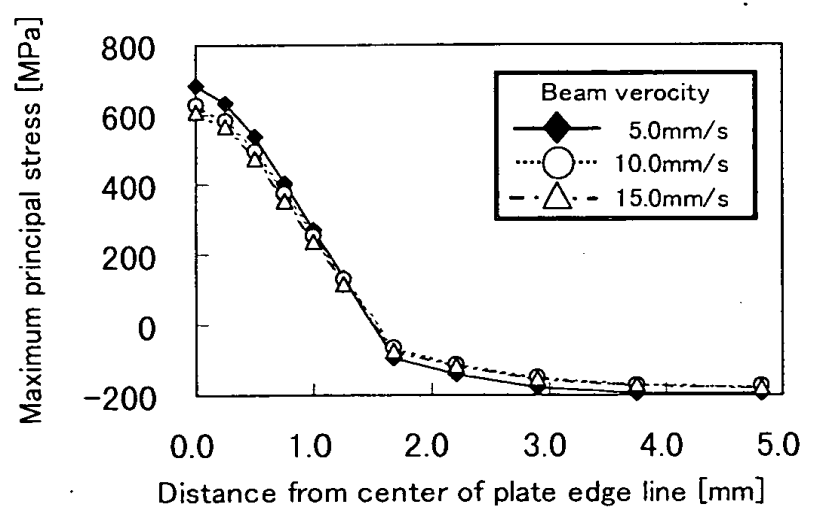

Fig. 15 Distribution of maximum principal stress for different beam velocities

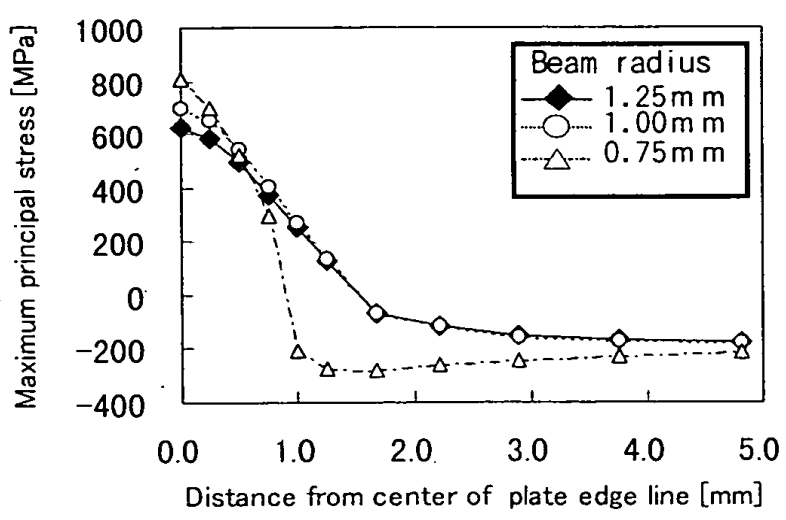

Fig. 16 Distribution of maximum principal stress for different beam radii
た最大主心力分布を示す・ビーム径が $1.25 \mathrm{~mm}$ の場 合は，0.25 秒後にビーム中心の位置が基板端から $125 \mathrm{~mm}$ の位置に移動したとき最大応力が基板端中央 上面に発生している。同様に，ビーム径が $1.00 \mathrm{~mm}$, $0.75 \mathrm{~mm}$ の場合もそれぞれ 0.25 秒後, 0.2 秒後に最大 応力が発生する. 最大応力か溌生している時刻は, 前 節で述べたビームが基板内部に移動し，基板端中央が ビーム照射領域外となる位置に移動したときにはぽ一 致している．1ステップ前後のずれは，解析による誤 差と考えている.

図 16 より，ビーム径が小さくなるほど，発生する 最大応力が高くなる。これはビーム径が小さいほど発 熱密度が高く，高温領域と基板端との距離も小さくな り，温度勾配が急峻になるためと考える。また，ビー 厶径が $1.25 \mathrm{~mm}$ と $1.00 \mathrm{~mm}$ の分布は形状はほぼ一致 しているが，0.75mm ではビーム径の近傍で急激に応 力が低下し，圧縮応力場に変化している。これは，ビ 一ムが最大応力発生位置, つまり基板端中央がビーム 照射領域外となる位置に移動した時刻が，0.75mm の 場合は早いため，熱伝導による熱拡散が淮まず，ビー 厶照射領域近傍の高温度領域の広がりが，前者2ケー スに比心小さく，ビーム径の影響を強く受けた結果と なるためである.

以上より，移動照射の場合は，ビーム径が小さい ほどき裂の発生は容易になり，また，初期き裂の発生 方向の偏向抑止に効果がある.

4.4 照射開始位置の影響 レーザの照射開始位置 の影響を検討するために，照射開始時のビーム照射領 域の中心の位置が，基板外，基板端から $125 \mathrm{~mm}$ 内部， 4.5mm 内部の場合を解析した.レーザ出力は $46 \mathrm{~W}$ ， ビーム径 $125 \mathrm{~mm}$ ，移動速度 $5.0 \mathrm{~mm} / \mathrm{s}$ とした。

図 17 は基板端中央上面の最大主応力の時間変化を 示す．基板外加照射したときは、入射当初圧縮応力 を示すが，その後急激に引張応力に変わる．照射開始. 位置を基板端とビーム照射領域外周が一致するように, ビーム中心を基板端からビーム半径に等しい $125 \mathrm{~mm}$ に設定すると、照射開始当初から基板端中央は引張応 力となり，0.15秒後に最大值 $864 \mathrm{MPa}$ を示した後，緩 やかに減少していく，さらに，照射開始位置を基板端 から離すと, 発生応力は低下する傾向を示す。

図 18 には，各照射開始位置条件で，基板端中央の 最大主応力が最大值を示す時刻の基板端の応力の分布 を示す．基板外から照射を開始した場合と基板端から ビーム径に等しい $1.25 \mathrm{~mm}$ だ離れた位置から照射を 開始した場合には応力分布はよく似た急峻な分布を示 す. 発生応力は基板端から $125 \mathrm{~mm}$ の位置から照射を 
開始した場合の方が高くなり，その結果，引張応力場 の範囲も広がっている。基板端から $4.5 \mathrm{~mm}$ はなれた 場合の応力分布はより緩やかになる.

したがって，照射は基板外から基板端の位置で開 始するのか勃果的である.

以上をまとめると，レーザを移動させて照射する 場合, 初期き裂の偏向抑止にはレーザのビーム径を小 さくすることおよび照射を基板端あるい基板外から開 始することが有効である。ビームの移動速度は低いほ どき裂の発生が容易になるが偏向の抑止効果は小さい.

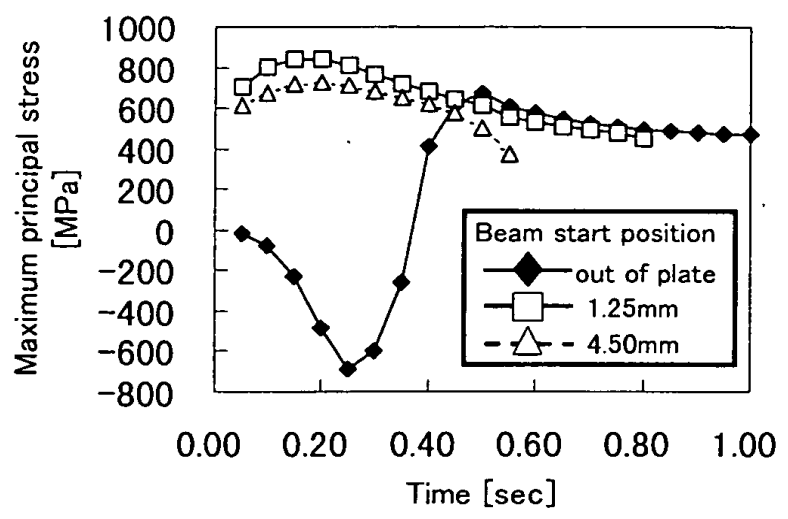

Fig. 17 Change of maximum principal stress at the center of plate edge for different beam starting position

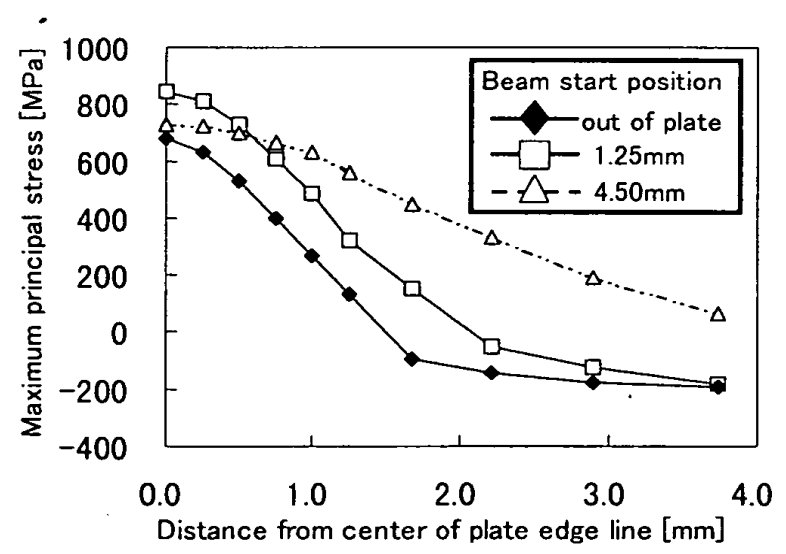

Fig. 18 Distribution of maximum principal stress for different beam starting position

5. 結言

アルミナ基板のレーザ割断において，初期き裂の 偏向を抑止するためには、基板端中央の応力を高く， その周囲では基板端に沿って急峻に応力が低下する分
布を形成することが有効であると考え，レーザの照射 条件をパラメータに熱応力解析を行い，初期き裂の発 生方向の偏向抑制の効果について検討した.

（1）レーザを静止照射する場合，照射位置は基板端 に近いほど偏向抑止の効果が大きい．

（2）ビー公径は小さいほどき裂の発生は容易になる が，偏向抑止への影響は小さい。

（3）レーザを移動照射する場合，ビーム径は小さい ほどき裂発生は容易になり，初期き裂の発生方向の偏 向抑止に効果がある.

（4）照射は基板外から基板端の位置で開始する方が 効果的である.

（5）ビームの移動速度は低いほどき裂の発生は容易 になるが，初期き裂の発生方向の偏向にはあまり効果 がない.

\section{謝辞}

本研究の遂行にあたり，有意義な議論を頂いた日立 電線株式会社 佐藤忍氏，於兽能啓一氏に感謝の意を 表す.

\section{文献}

（1）沖山侁裕，精密工学会誌，60-2，(1994)，196-199.

（2）鈴木清，機械と工具，39-3，(1995)，42-45.

（3）黑部利次，碈䊉加工学会誌，39-1，(1995)，10.

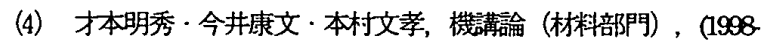
11), 5354

（5）沢田博司 - 今井康文 · 才本明秀 - 本村文考, 精密工学会誌 64-11, (1998), 1638-1642.

(6) A.Saimoto, YImai and H.Sawada, Advanoes in Fracture Research, ICF9, (1997), 2095.

（7）山田啓司・上田隆司・緗川晃・マフズアルフダ，大磯桂一， 機講論, No.98-5(1998-11), 53-54

(8) W. Kniegel and H. Palmour III, Mecahnical properties of engineering œramics, Interscienœ publishers, (1961)

（9）川田雄一・河本実・横䖯武夫 - 宮川松男編, 材料強度工学 ハンドブック，朝倉書店，(1977), $788-791$

(10) H.Nakayama, CERAMICSSTRENGTHDATABASE, 日 本材料学会, (1996), 262 